\title{
Sustainable development of Russian companies participating in United Nations Global Compact
}

\author{
Konstantin Belousov ${ }^{*}, 1$ \\ ${ }^{1}$ Saint-Petersburg State University, Faculty of Economics, Department of Economic Theory and \\ Social Policy, 191194 Tchaikovskogo str. 62, Saint Petersburg, Russian Federation
}

\begin{abstract}
Research background: This article presents the results of a study of nonfinancial reporting in the field of sustainable development of Russian companies within the United Nations Global Compact initiative.

Purpose of the article: The purpose of this study is to identify preferred direction of companies. We put their reports on sustainable development in Triple bottom line (TBL) areas: social, environmental and economic. In this article I also disclose conceptual foundations of sustainable development, which served as theoretical and methodological basis of the study.

Methods: Analysis of the companies activities in the field of sustainable development, the results of which are reflected in corporate reports on sustainable development for 2018, 2019, 2020, which passed the nonfinancial audit procedures of the Russian Union of Industrialists and Entrepreneurs and are published in the reports register.

Findings \& Value added: The study made it possible to identify companies through the positioning of their reports on sustainable development. The study confirmed the hypothesis that non-financial reports on sustainable development are social in nature, focusing on the interests of staff and consumers, while environmental and economic aspects are given less importance. The articles also disproves the hypothesis, that the direction of the company has a significant impact on the positioning of the company. In the course of the study, it became possible to assess the companies' support for the Global Compact initiatives.
\end{abstract}

Keywords: Global Compact; non-financial reporting; sustainable development of the company; corporate sustainability; corporate sustainable development

JEL Classification: $Q 01 ; Q 56 ; M 14$

${ }^{*}$ Corresponding author: belloussov@mail.ru 


\section{Introduction}

The history of the problem of sustainable development is related to the mid-twentieth century and is inseparably linked with the emergence of the Club of Rome and the sensational reports "The Limits to Growth", "Mankind at the Turning Point". One of the incentives for the transition to a new paradigm of development was science ecologization. The background of the formation of sustainable development one can divide into three categories according to the logic of the Triple bottom line (TBL) approach: environmental, social and economic.

Among the ecological incentives, the problems of exhaustion of natural resources, environmental pollution, the threat of technological disasters, violation of biological diversity, desertification and reduction of forests, global warming and thinning of the ozone layer, the occurrence of climate anomalies, and so on, clearly appeared. As for the social and socio-economic prerequisites for sustainable development, world poverty and gender inequality, the creation of modernization centers, lagging, discrimination, overpopulation, a gap in social standards of life and poor social infrastructure were vividly distinguished. Among the economic prerequisites for sustainable development, the problems of expansive business behavior, corporate irresponsibility, models of irresponsible production and consumption, energy and resource dependence, irrational distribution of resources, the gap in incomes, unemployment were updated.

In other words, throughout the first half of the twentieth century, scientists perceived a man as the "king of nature" (who is able to subjugate and control all its elements: from visible to invisible). On contrary during the entire second half of the century a man was a main source of global problems and the cause of the crisis of sustainable development.

At the initial stage, scientists from leading countries of the world performed calculations on the global modeling of the processes of development of world civilization. Computer technology made it possible to build the first mathematical models based on a system of integral equations. In 1970, J. Forrester developed the first global development models, World-1 and World-2. In 1972, under the leadership of D. Meadows, the World-3 model was developed, which used five variables: capital investment, population, food, natural resources and environmental pollution. Unfortunately, the report by the Club of Rome entitled "The Limits to Growth" and the World-3 model used in it, created a contradiction between "sustainable development" and "sustainable economic growth". Only in 1987, in the report "Our Common Future" by the International Commission on Environment and Development, when the principle of "zero growth" was finally replaced by the principle of "organic growth", was it determined that economic growth should fit within the ecological possibilities the planet.

At the same time, the report of G. Bruntland "Our Common Future" laid down another contradiction between the economy and sustainable development. Thus, according to the classic definition, "sustainable development" is understood as such a development of world civilization, in which the satisfaction of the vital needs of current generation is achieved without harming future generations. However, commercial organizations do not exist for hundreds or even decades. J. Elkington noted (Elkington, 2010, p. 115) that the average life span of a company is too short for it to raise an interest in global sustainable development and the ability of future generations to satisfy their needs at the same level as the current.

It is believed that the most significant principles of sustainable development were set out in 1992 during the World Conference on Environment and Development, held under the aegis of the UN in Rio de Janeiro. One of the main documents adopted at the Conference was Agenda 21. The UN Conference in Rio de Janeiro, as well as the subsequent Conference in Copenhagen with its 10 commitments, did not resolve the contradictions of the economy and sustainable development. Agenda 21 remained an overly globalized 
document giving recommendations to global regulators - states and governments, while losing sight of business.

In January 1999, the Global Compact was introduced by UN Secretary-General K. Annan at the World Economic Forum in Davos. This agreement offers a system of relations between business, government and society, forming a sustainable and open global economy. Participation in the contract significantly expanded business opportunities, which was manifested in demonstrating the company's leading position in terms of implementing socially responsible behavior, integrating into the global values system and improving corporate governance methods and strategic planning effectiveness (Kanaeva, 2013, 2018).

The Global Compact has expanded the concept of sustainable development to the level of business organizations, becoming the missing link in the evolution of the concept. The creation of the Global Compact was an important milestone in the transition of the concept of sustainable development to the microeconomic level. Sustainable development has come to be understood as the creation by a company of a long-term shared value. For Russian companies, this is necessary for participating in an international IPO.

Currently, there are several valuable studies of the Global Compact in the scientific literature. In addition to an overview and analytical articles examining the history and development prospects of the Global Compact (Berliner and Prakash, 2014; Kell, 2013; Orzes et al., 2018; Rasche et al., 2013) or the essence of the initiative (Bauer, 2015; Bremer, 2008; Brown, 2018; Rasche, 2009, 2012), there are researches with pragmatic essence of the Compact initiative. However, their number is small.

D. Cetindamar and K. Husoy conducted a study in 2007 aimed at exploring the incentives and benefits of joining United Nations Global Compact (UNGC). As a result, the authors revealed that there are ethical and economic reasons for integrating the principles of sustainable development into corporate activity: providing network opportunities, improving the corporate image, the accumulation of reputation capital, a positive impact on their commercial results (Cetindamar \& Husoy, 2007). In 2009, A. Rasche investigated accountability standards for Global Compact. The study analyzes how this initiative differs from other standards, and highlights its strengths and weaknesses in accordance with the non-financial reporting model (Rasche, 2009).

In 2014, S. P. Sethi, and D. H. Schepers examined the activities of the Global Compact and its impact on enhancing corporate social responsibility. The authors conclude that the initiative was unable to encourage signatories to step up their real CSR efforts and integrate 10 principles into their policies and governance. In fact, signing a contract does not mean real changes in corporate behavior. The authors question the practical usefulness and ability of further development of the UNGC (Sethi \& Schepers, 2014).

In June 2015, on the occasion of the 15th anniversary of UNGC, DNV GL conducted a study and prepared the "Global Compact 15 Report: Transforming Business, Changing The World". The report noted such driving forces that contribute to the integration of the principles of sustainable development, such as: mobilizing a business, adapting corporate goals, turning sustainable development activities into everyday activities, improving management, enhancing consumer actions in partnership with business and rethinking the concept of corporate leadership (Global Compact 15 Report, 2015).

In 2015, M. Coulmont and S. Berthelot reviewed the benefits for companies affiliated with UN Global Compact. The study was based on a sample of French companies included in the SBF 250 index. The results show that, at least in the French context, investors greatly value the firm's membership in the UN Global Compact (Coulmont \& Berthelot, 2015). In 2018 , S. Schembera conducted a study and concluded that participation in the UNGC affects the level of implementation of the principles of sustainable development in the activities of organizations (Schembera, 2018). 
In 2019 E. Amer conducted a study that examined the issue of accountability mechanisms. Companies that joined the UNGC should annually submit a report on environment, social sphere and management to the UNGC Communication on Progress (COP). The voluntary nature of the initiative and the lack of external control mechanisms and sanctions make it ineffective in terms of the implementation of sustainable development principles by business participants (Amer, 2019). Also in 2019, D. Abdelzaher, W. D. Fernandez and W. D. Schneper, based on a neo-institutional and crosscountry comparative analysis, examined the impact of the legal rights of stakeholders, the influence of national culture and the country's position in the structure of international trade. The results showed that companies from countries with strong stakeholder influence, transparent culture and long-standing stock trading traditions are joining the UNGC at a faster pace (Abdelzaher et al., 2019). In the same year, D. Baeumlisberger conducted an analysis of the problems of the UN Global Compact. In particular, the author noted that the agreement faces difficulties in attracting new voluntary members and in encouraging them to implement ten principles of sustainable development. The author made an attempt to consider the UNGC in terms of Locke's theory of social contracts and identify strategies to eliminate its problems and contradictions (Baeumlisberger, 2019).

\section{Methods}

While conducting this research, I focused on the positioning of non-financial reports in the field of sustainable development in their TBL areas.

The object of the study was Russian companies from the RBC 500 rating, which joined the UN Global Compact initiative and issued non-financial statements verified by the Russian Union of Industrialists and Entrepreneurs.

The subject of analysis was the activities of these companies in the field of sustainable development, the results of which are reflected in corporate reports on sustainable development for 2018, 2019, 2020, which passed the non-financial audit procedures of the Russian Union of Industrialists and Entrepreneurs and are published in the reports register.

The aim of our study of non-financial reporting is to identify the preferred direction of companies through positioning their reports on sustainable development among the three main TBL areas: social, environmental and economic.

In my research I used content analysis in reporting as a main methodological approach. The results were processed using the Gibbs-Rosebom triangle model (shown in the Figure 3), described in the article by A. Kleine and M. Hauff (Kleine and Hauff, 2009), calculated on a computer in Excel.

Two research hypotheses have been put forward. First one included the fact that nonfinancial reports on sustainable development are social in nature, focusing on the interests of staff and consumers, while environmental and economic aspects are given less importance. Second one poses the fact that the direction of the company has a significant impact on the positioning of the report.

The study is based on the content analysis of non-financial report texts. Content analysis uses three groups of search words related to one of the TBL areas: social, environmental, and economic. Content analysis is performed using a software package that searches for keywords in the selected text. The influence of cases and the number of words used is taken into account. The search does not take into account the area of GRI correspondence tables and applications after the report. As a result of the analysis, it is possible to identify the orientation of the report and the degree of violation in it of the principle of equivalence of sustainable development directions.

At 2021 more than 10498 companies (total 13914 commercial, non-profit and academic organizations) from 160 countries of the world have joined the agreement. 68 organizations 
have joined the initiative from the Russian Federation. They were distributed as follows (shown in the Fig. 1.): 31 - Local \& Global NGO, Academic \& Associations, 10 - Basic Resources (Industrial Metals \& Mining), 5 - Industrial Goods \& Services, 4 - Oil \& Gas Producers sector, 2 - Chemicals, 2 - Utilities (Electricity), 3 - Real Estate, 3 - Banks, 3 Financial Services, 2 - Technology (Software \& Computer Services), 1 - Construction \& Materials, 1 - Media, 1 - Retail. Among the Russian organizations that have entered into the initiative, there are no companies from the following sectors: Personal \& Household Goods, Food \& Beverage, Automobiles \& Parts, Health Care, Telecommunications, Travel $\&$ Leisure, Insurance. 31 organizations are NGOs or business associations.

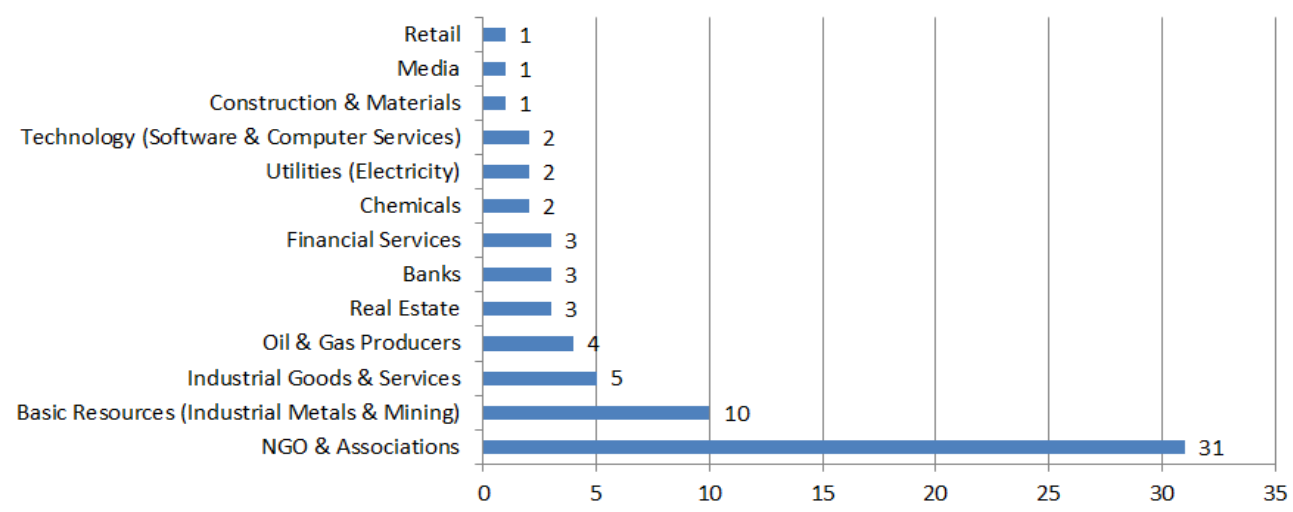

Figure 1. Distribution by industry of Russian organizations in Global Compact

Source: author (2021)

At the same time, it is important to note that none of the organizations has reporting on SDGs and Financial innovation for the SDGs, and only 37 companies are directly related to business. Of these, 9 companies belong to the «Small or Medium-sized Enterprise» category, and 28 to the «Company» category.

Within the framework of the UN Global Compact, 20 individual initiatives are being implemented related to pressing issues of the Sustainable Development Goals. Of the 37 business organizations, not all companies actively supported these initiatives. For example, only United Company RUSAL supported the "Carbon Pricing Champions" initiative aimed at setting a price per carbon emissions of at least $\$ 100$ per metric ton for the purpose of its further cost accounting. Only EN + GROUP IPJSC (Industrial Metals \& Mining) supported the "Science Based Targets" and "Business Ambition for $1.5^{\circ} \mathrm{C}$ - Our Only Future" initiatives, which aim to limit the global temperature rise to $1.5^{\circ} \mathrm{C}$ until 2050.2 companies (The Svirin Family Company and United Company RUSAL) shared the UN Global Compact "Caring For Climate" initiative, whose participants sign a formal commitment to take practical climate action. This may include, for example, setting targets for reducing greenhouse gas emissions. Two companies (The Svirin Family Company and ACIG Group of Companies) supported the UN "Business for Peace Signatories" initiative aimed at implementing principles of sustainable development in socially unstable regions.

Two Russian companies (PJSC PhosAgro Company and Sakhalin Energy Investment Company Ltd.) shared the Global Compact LEAD initiative, the essence of which is to bring together concerned companies with relevant experts and stakeholders to work together to create and implement best practices for sustainable development. Two companies (EN + GROUP IPJSC and The Svirin Family Company) supported the CEO Water Mandate initiative. Sakhalin Energy Investment Company Ltd. became the only 
company from Russia to support the "Human Rights and Labor Working Group", and The Svirin Family Company - the "Women's Empowerment Principles".

For comparison: in Germany 527 organizations joined Global Compact (486 of which are business organizations), in France - 1254 (1169), in the USA - 590 (409), in England 540 (405), in China - 304 (275), in neighboring to Russia Finland - 86 (84). On the territory of the post-Soviet space (shown in Fig. 2.): 26 organizations joined in Belarus (of which 20 are business organizations), 62 (29) in Ukraine, 34 (19) in Georgia, 29 (19) in Lithuania , in Kazakhstan - 13 (11), in Azerbaijan 10 (2), in Latvia - 8 (4), in Estonia - 3 (3), in Moldova - 3 (3), in Armenia - 2 (1), in Uzbekistan - 1 (0), in Kyrgyzstan 1 (0), in Tajikistan and Turkmenistan $-0(0)$. This allows us to conclude that the Russian Federation and Ukraine occupy leading positions in relations with the United Nations Global Compact in the post-Soviet space, but this participation is insignificant in comparison with developed countries. The share of Russian business in Global Compact is small and amounts to only $0.35 \%$ (37 Russian companies out of 10498).

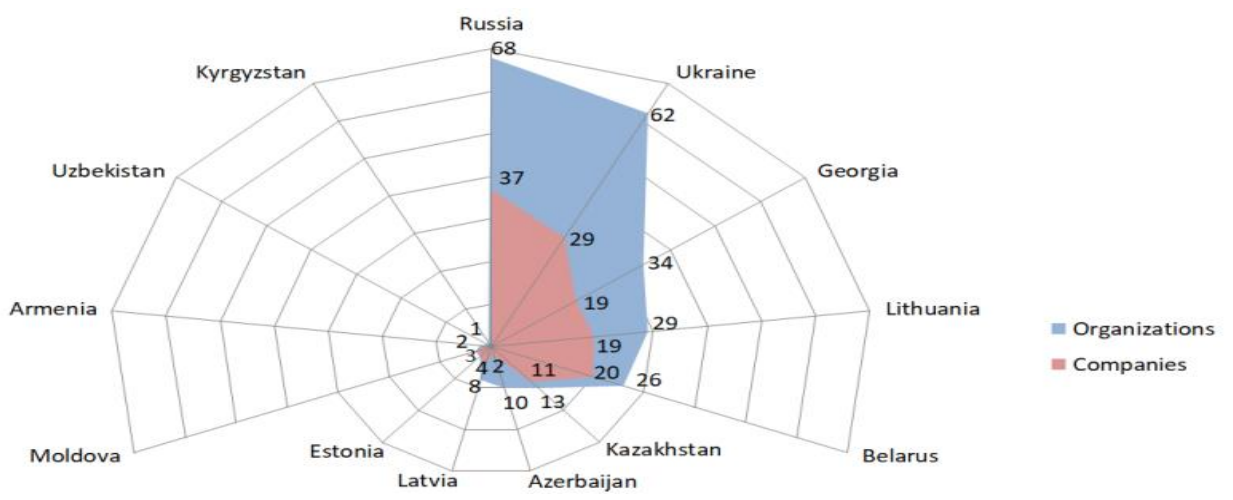

Figure 2. Organizations and companies that joined the Global Compact (post-Soviet countries)

Source: author (2021)

A comparative analysis of the list of Russian companies in Global Compact and the Russian Business Rating of RosBusinessConsulting (RBC) 500 (Russia's 500 largest revenue companies in 2020) shows that of the 28 large companies that entered into the Global Compact initiative, 25 are included in the RBC rating as with the largest revenue in Russia (shown in Tab. 1). The rating does not include FBK LLC (Financial Services), JSC "Interstate Corporation for Development" and ACIG Group of Companies.

Of the 25 companies that entered into the Global Compact initiative, RBC 500, the National Register of Corporate Non-Financial Reports of the Russian Union of Industrialists and Entrepreneurs, only 14 companies established reports on sustainable development in 2018-2020 reporting year (National Register, 2021). JSC Russian Railways has reports on corporate social responsibility only. Over the past three years PJSC Inter RAO, PJSC Tatneft, PJSC PhosAgro have completely switched to integrated reporting. Nordgold last reported in 2012, and currently there are no verified reports in the field of sustainable developmnent in the reporting registry. Over the past 2 years, PJSC RusHydro has switched to integrated reporting, but it has a report on sustainable development for 2016. In the period from 2010-2016, Petropavlovsk PLC issued only corporate social responsibility reporting. The companies EN + Group IPJSC, NLMK Group, PIK Group, PJSC Sovcombank and SAP C.I.S do not have non-financial statements that have been audited or verified by experts of the Russian Union of Industrialists and Entrepreneurs. 
Table 1. Large Russian companies that joined the Global Compact in the RBC 500 ranking.

\begin{tabular}{|c|c|c|c|c|}
\hline \multirow[b]{2}{*}{ Company } & \multirow{2}{*}{$\begin{array}{c}\text { Sector (by Global } \\
\text { Compact } \\
\text { classification) }\end{array}$} & \multirow{2}{*}{$\begin{array}{c}\text { Pos. in } \\
\text { RBK500 } \\
\text { (by } \\
\text { Revenue) } \\
\end{array}$} & Revenue & Profit \\
\hline & & & \multicolumn{2}{|c|}{ in billions of rubles } \\
\hline Lukoil & Oil \& Gas Producers & $2(-)$ & $7479(+37 \%)$ & $\begin{array}{c}1456 \\
(+47 \%)\end{array}$ \\
\hline Rosneft Oil & Oil \& Gas Producers & $3(-)$ & $6850(+36 \%)$ & $549(+85 \%)$ \\
\hline Russian Railways & $\begin{array}{c}\text { Industrial } \\
\text { Transportation }\end{array}$ & $5(-)$ & $2413(+7 \%)$ & $35(+75 \%)$ \\
\hline PJSC Inter RAO & Electricity & $12(\downarrow)$ & $963(+5 \%)$ & $71(+30 \%)$ \\
\hline PJSC Tatneft & Oil \& Gas Producers & $14(-)$ & $911(+34 \%)$ & $212(+71 \%)$ \\
\hline Sistema PJSFC & $\begin{array}{l}\text { Investment } \\
\text { Instruments }\end{array}$ & $16(-)$ & $777(+12 \%)$ & $-38(-)$ \\
\hline EN+ Group IPJSC & $\begin{array}{c}\text { Industrial Metals \& } \\
\text { Mining } \\
\end{array}$ & $16(-)$ & $776(+10 \%)$ & $117(+43 \%)$ \\
\hline NLMK Group & $\begin{array}{c}\text { Industrial Metals \& } \\
\text { Mining }\end{array}$ & $17(\uparrow)$ & $756(+29 \%)$ & $140(+66 \%)$ \\
\hline PJSC NorNickel & $\begin{array}{c}\text { Industrial Metals \& } \\
\text { Mining }\end{array}$ & $18(\uparrow)$ & $729(+36 \%)$ & $189(+48 \%)$ \\
\hline UC RUSAL & $\begin{array}{c}\text { Industrial Metals \& } \\
\text { Mining }\end{array}$ & $21(\downarrow)$ & $645(+11 \%)$ & $106(+49 \%)$ \\
\hline $\begin{array}{l}\text { PJSC SIBUR } \\
\text { Hold. }\end{array}$ & Chemicals & $23(\uparrow)$ & $569(+25 \%)$ & $106(-9 \%)$ \\
\hline Severstal & $\begin{array}{c}\text { Industrial Metals \& } \\
\text { Mining }\end{array}$ & $24(\downarrow)$ & $537(+17 \%)$ & $129(-12 \%)$ \\
\hline $\begin{array}{l}\text { Metalloinvest } \\
\text { LLC }\end{array}$ & $\begin{array}{c}\text { Industrial Metals \& } \\
\text { Mining }\end{array}$ & $29(\uparrow)$ & $450(+24 \%)$ & $100(+28 \%)$ \\
\hline PJSC PhosAgro & Chemicals & $30(\uparrow)$ & $233(+29 \%)$ & $22(-13 \%)$ \\
\hline PJSC RusHydro & Electricity & $32(\downarrow)$ & $400(+5 \%)$ & $31(+26 \%)$ \\
\hline $\begin{array}{c}\text { Sakhalin Energy } \\
\text { Ltd }\end{array}$ & Oil \& Gas Producers & $33(\uparrow)$ & $393(+25 \%)$ & $128(+46 \%)$ \\
\hline VEB.RF & Banks & $50(\downarrow)$ & $297(-1 \%)$ & $-172(-)$ \\
\hline PIK Group & Real Estate Investment & $56(\uparrow)$ & $246(+40 \%)$ & $21(+574 \%)$ \\
\hline PJSC Polyus & Mining & $80(-)$ & $185(+16 \%)$ & $29(-59 \%)$ \\
\hline LSR Group & $\begin{array}{c}\text { Construction \& } \\
\text { Materials }\end{array}$ & $105(\downarrow)$ & $146(+6 \%)$ & $16(+2 \%)$ \\
\hline Polymetal PLC & $\begin{array}{c}\text { Industrial Metals \& } \\
\text { Mining }\end{array}$ & $121(\downarrow)$ & $118(+11 \%)$ & $22(+8 \%)$ \\
\hline $\begin{array}{c}\text { PJSC } \\
\text { Sovcombank }\end{array}$ & Banks & $127(\uparrow)$ & $112(+26 \%)$ & $17(-41 \%)$ \\
\hline Nordgold & Mining & $186(\downarrow)$ & $72(+1 \%)$ & $6(-41 \%)$ \\
\hline SAP C.I.S & Software \& Computers & $332(-)$ & $35(+10 \%)$ & $0,5(+41 \%)$ \\
\hline $\begin{array}{c}\text { Petropavlovsk } \\
\text { PLC } \\
\end{array}$ & Mining & $360(\downarrow)$ & $31(-9 \%)$ & $4(+46 \%)$ \\
\hline
\end{tabular}

Source: author (2021) 
The further analysis is carried out in the field of sustainable development reports of those 14 companies that are included in the RSPP register. For this purpose, their reports were selected for the 2018-2020 years. Based on preliminary data, we hypothesized that non-financial reports on sustainable development are social in nature, focusing on the interests of staff and consumers, while environmental and economic aspects are given less importance, which, according to the study we examined in the previous paragraph, typical for Russian business organizations. A similar imbalance inherent in corporate social responsibility reports would indicate a duplication of these reports with reports in the field of sustainable development. The second hypothesis is that the direction of the company has a significant impact on the positioning of the report.

The Table 2 shows the results of a content analysis of non-financial reports in the field of sustainable development. The data are converted to a percentage $(X+Y+Z=100 \%)$, where $\mathrm{X}$ is the social TBL component of non-financial report on sustainable development, $\mathrm{Y}$ is environmental, $\mathrm{Z}$ is economic. $\mathrm{X} 1, \mathrm{Y} 1$ and $\mathrm{Z1}$ are TBL components of the 2018 reports, X2, Y2 and Z2 are the 2019 reports, X3, Y3, Z3 are the 2020 reports, Xa, Ya and $\mathrm{Za}$ are the average values of the report components for the last three years (2018-2020).

Table 2. Results of content analysis of non-financial reports in the field of sustainable development

\begin{tabular}{|c|c|c|c|c|c|c|c|c|c|c|c|c|c|}
\hline \multirow{3}{*}{ Company } & \multirow{3}{*}{$\begin{array}{c}\text { Sector (by } \\
\text { Global } \\
\text { Compact } \\
\text { classification } \\
\text { ) }\end{array}$} & \multicolumn{9}{|c|}{$\begin{array}{c}\text { Sustainable development report (distribution } \\
\text { of TBL components; \%) }\end{array}$} & \multirow{2}{*}{\multicolumn{3}{|c|}{$\begin{array}{c}3 \text { year } \\
\text { average } \\
(\%)\end{array}$}} \\
\hline & & \multicolumn{3}{|c|}{2018} & \multicolumn{3}{|c|}{2019} & \multicolumn{3}{|c|}{2020} & & & \\
\hline & & $\begin{array}{c}\mathbf{X} \\
\mathbf{1}\end{array}$ & $\begin{array}{l}\mathbf{Y} \\
\mathbf{1}\end{array}$ & $\begin{array}{l}\mathbf{Z} \\
\mathbf{1}\end{array}$ & $\begin{array}{l}X \\
2\end{array}$ & $\begin{array}{l}\mathbf{Y} \\
\mathbf{2}\end{array}$ & $\begin{array}{l}\mathbf{Z} \\
\mathbf{2}\end{array}$ & $\begin{array}{l}\mathbf{X} \\
\mathbf{3}\end{array}$ & $\begin{array}{l}\mathbf{Y} \\
\mathbf{3}\end{array}$ & $\begin{array}{l}\mathbf{Z} \\
\mathbf{3}\end{array}$ & $\begin{array}{l}\mathbf{X} \\
\mathbf{a}\end{array}$ & Y & $\begin{array}{l}\mathbf{Z} \\
\mathbf{a}\end{array}$ \\
\hline Lukoil & Oil \& Gas & 50 & 26 & 24 & 58 & 30 & 12 & 61 & 12 & 27 & 56 & 23 & 21 \\
\hline Rosneft Oil & Oil \& Gas & 80 & 20 & 0 & 65 & 20 & 15 & 71 & 15 & 14 & 72 & 18 & 10 \\
\hline $\begin{array}{l}\text { Sakhalin } \\
\text { Energy }\end{array}$ & Oil \& Gas & 58 & 27 & 15 & 55 & 31 & 14 & 55 & 31 & 14 & 56 & 30 & 14 \\
\hline Severstal & $\begin{array}{l}\text { Metals \& } \\
\text { Mining }\end{array}$ & 59 & 25 & 16 & 66 & 17 & 17 & 64 & 21 & 15 & 63 & 21 & 16 \\
\hline $\begin{array}{l}\text { Metalloinves } \\
\text { t LLC }\end{array}$ & $\begin{array}{l}\text { Metals \& } \\
\text { Mining }\end{array}$ & 60 & 20 & 20 & 58 & 20 & 22 & 50 & 26 & 24 & 56 & 22 & 22 \\
\hline $\begin{array}{c}\text { PJSC } \\
\text { NorNickel }\end{array}$ & $\begin{array}{l}\text { Metals \& } \\
\text { Mining }\end{array}$ & \multicolumn{3}{|c|}{ Not available } & 61 & 26 & 13 & 45 & 25 & 30 & 53 & 26 & 22 \\
\hline UC RUSAL & $\begin{array}{l}\text { Metals \& } \\
\text { Mining }\end{array}$ & 44 & 33 & 23 & 55 & 20 & 25 & \multicolumn{3}{|c|}{ Not available } & 50 & 27 & 24 \\
\hline $\begin{array}{l}\text { Polymetal } \\
\text { PLC }\end{array}$ & $\begin{array}{l}\text { Metals \& } \\
\text { Mining }\end{array}$ & 35 & 36 & 29 & 54 & 22 & 24 & \multicolumn{3}{|c|}{ Not available } & 45 & 29 & 27 \\
\hline PJSC Polyus & Mining & \multicolumn{3}{|c|}{ Not available } & \multicolumn{3}{|c|}{ Not available } & 55 & 25 & 20 & 55 & 25 & 20 \\
\hline $\begin{array}{l}\text { PJSC SIBUR } \\
\end{array}$ & Chemicals & 53 & 26 & 21 & 46 & 26 & 28 & \multicolumn{3}{|c|}{ Not available } & 50 & 26 & 25 \\
\hline $\begin{array}{c}\text { PJSC } \\
\text { RusHydro }\end{array}$ & Electricity & 56 & 34 & 10 & \multicolumn{3}{|c|}{ Not available } & \multicolumn{3}{|c|}{ Not available } & 56 & 34 & 10 \\
\hline LSR Group & Construction & \multicolumn{3}{|c|}{ Not available } & \multicolumn{3}{|c|}{ Not available } & 60 & 21 & 19 & 60 & 21 & 19 \\
\hline $\begin{array}{l}\text { Sistema } \\
\text { PJSFC }\end{array}$ & $\begin{array}{l}\text { Investment } \\
\text { Instr. }\end{array}$ & 35 & 35 & 30 & 51 & 25 & 24 & \multicolumn{3}{|c|}{ Not available } & 43 & 30 & 27 \\
\hline VEB.RF & Banks & 45 & 33 & 22 & 64 & 13 & 23 & \multicolumn{3}{|c|}{ Not available } & 55 & 23 & 23 \\
\hline
\end{tabular}

Source: author (2021)

\section{Results and Discussion}

1. Identification of the preferred direction of companies through the positioning of their reports on sustainable development of companies. The results of the study showed that most companies exceeded the social TBL component. Reports in which the social TBL component $(\mathrm{X})$ is $50 \%$ or more can be characterized as "mainly social". There are 10 of 
these companies. The reporting policy of 2 companies (Sistema PJSFC and Polymetal PLC) allows us to call their sustainable development reports balanced. The reports of 2 companies (PJSC RusHydro and Sakhalin Energy) can be described as social and environmental. Earlier studies using a similar technique (Belousov, 2020; Kanaev, 2018, 2019) showed that in most cases companies position their reports on sustainable development as social and predominantly social. These results allow us to conclude that there is a violation of the principle of balance.

2. The hypothesis that non-financial reports on sustainable development are social in nature, focusing on the interests of staff and consumers, while environmental and economic aspects are given less importance. This hypothesis is confirmed, since 10 out of 14 companies are characterized as "mainly social". The qualitative analysis outlines that such reports in the field of sustainable development are close to reports on corporate social responsibility in structure and content.

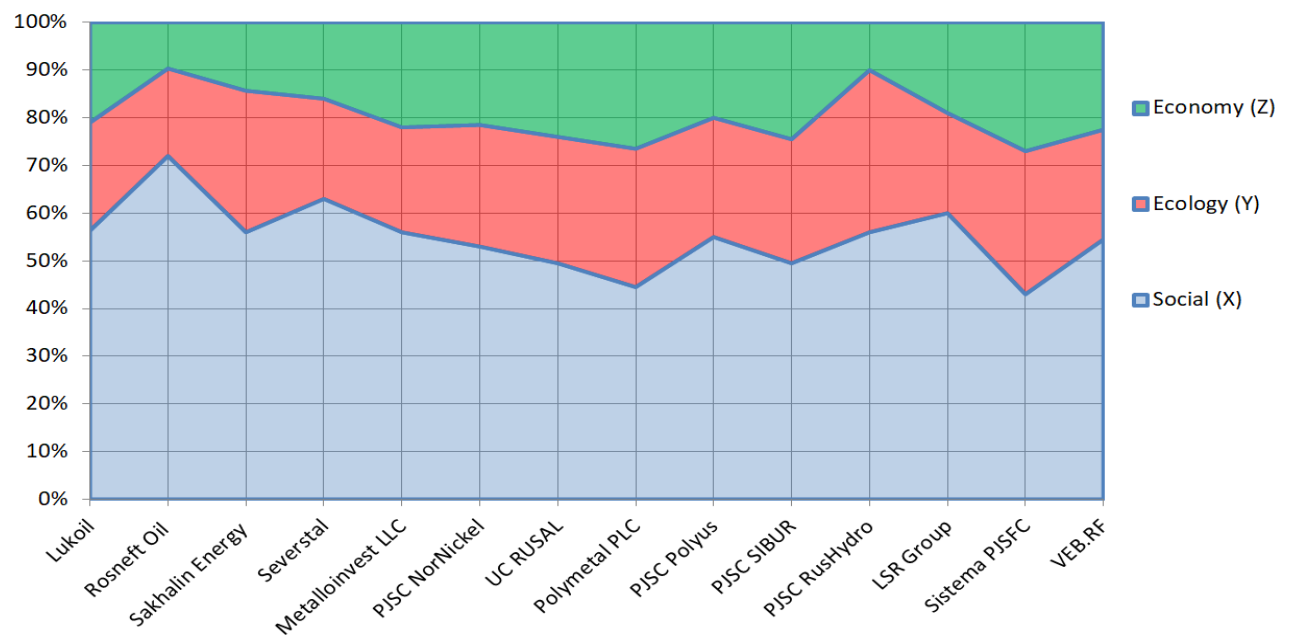

Figure 2. Positioning non-financial reports in the field of sustainable development by their TBL components

Source: author (2021)

3. The hypothesis that the direction of the company has a significant impact on the positioning of the company. This hypothesis is disproved, since the dependence of positioning in TBL directions on the basis of activity has not been identified. Guided by the logic of the hypothesis, 11 out of 14 were supposed to show the confident positioning of their reports as ecological, since these companies represent potentially hazardous for the environment industries Oil \& Gas, Metals \& Mining, Chemicals and Electricity. This was not proved, and companies positioned themselves as "predominantly social."

4. Support for individual Global Compact initiatives. Of the 20 individual initiatives related to the actual issues of the Sustainable Development Goals, Russian companies supported 10. Only 6 out of 37 business organizations joined the initiatives. The Svirin Family Company supported 4 initiatives, EN + GROUP IPJSC supported 3, Sakhalin Energy Investment Company Ltd. had also 3, United Company RUSAL - 2 of them, ACIG Group of Companies only 1, PJSC PhosAgro Company only 1. Other initiatives were not supported by Russian business. Among them were questions in the areas of anti-corruption, child labor, responsible climate policy, sustainable stock exchanges, supply chain advisory and many others. This allows us to conclude that these problems are not perceived by the Russian business community as relevant. 
5. The results of a comparative analysis of the list of Russian companies in Global Compact and the Rating of Russian business in RBC 500. Based on these data, two conclusions can be drawn. Firstly, Russian companies that joined the Global Compact are mainly leading companies with large revenues of more than 30 billion rubles a year. Secondly, these companies are usually associated with Oil \& Gas Producers or Mining.

This research give an advantage in future analysis of Russian companies that entered the Global Compact. At present, an international business community seeks to cooperate in the interest of solving global problems of sustainable development. For this reason it is important to understand the role and place of Russian companies in this process. Unfortunately, despite the positive picture among post-Soviet countries, the integration of sustainable development principles into Russian business is unreasonably slow. This study allows us to begin a deeper analysis of the situation and formulate further recommendations on improving the process of integrating principles of sustainable development into the corporate governance of Russian companies.

\section{References}

1. Abdelzaher, D., Fernandez, W. D., \& Schneper, W. D. (2019). Legal rights, national culture and social networks: Exploring the uneven adoption of United Nations Global Compact. International Business Review, 28(1), 12-24.

2. Amer, E. (2018). The penalization of non-communicating un global compact's companies by investors and its implications for this initiative's effectiveness, Business \& Society, 57(2), 255-291.

3. Baeumlisberger, D. (2019). The United Nations global compact as a facilitator of the lockean social contract. Journal of Business Ethics, 159(1), 187-200.

4. Bauer, J. (2015). Sustainable development: The UN millennium development goals, the UN global compact, and the common good. Enterprise \& Society, 16(1), 202-204.

5. Belousov, K. (2020). From corporate social responsibility to sustainable development of modern business: The case of Russia. New challenges in economic and business development - 2020: Economic inequality and well-being, 78-89.

6. Belousov, K. (2020). Corporate social responsibility and sustainable development of modern russian companies as a challenge of business globalization. SHS Web of Conferences, 74(06004).

7. Berliner, D., \& Prakash, A. (2014). The United Nations global compact: An institutionalist perspective. Journal of Business Ethics, 122(2), 217-223.

8. Bremer, J. A. (2008). How global is the Global Compact? Business Ethics - a European Review, 17(3), 227-244.

9. Brown, J. A., Clark, C., \& Buono, A. F. (2018). The United Nations Global Compact: Engaging implicit and explicit CSR for global governance. Journal of Business Ethics, 147(4), 721-734.

10. Cetindamar, D., \& Husoy, K. (2007). Corporate social responsibility practices and environmentally responsible behavior: The case of the United Nations Global Compact. Journal of Business Ethics, 76(2), 163-176.

11. Coulmont, M., \& Berthelot, S. (2015). The financial benefits of a firm's affiliation with the UN Global Compact. Business Ethics-A European Review, 24(2), 144-157.

12. Elkington, J. (2010). Corporate sustainability. In: W. Visser (Ed.), The A to $Z$ of corporate social responsibility. Chichester, West Sussex, U.K., Wiley. 114-119. 
13. Global Compact 15 Report: Transforming Business, Changing the World. DNV. https://www.dnvgl.com/about/sustainability/impact/index.html.

14. Kanaev, A., Kanaeva, O., \& Belousov, K. (2019). Sustainable development of Russian companies: Specifics of interpretation and directions of activities. Proceedings of the Third International Economic Symposium (IES 2018). St Petersburg: Atlantis Press, 61-73.

15. Kanaev, A.V., Kanaeva, O. A., \& Belousov, K. Yu. (2018). Transition to the sustainable development model: The practice of Russian companies. New Challenges of Economic and Business Development. Productivity and Economic Growth Proceedings. Riga: University of Latvia, 302-313.

16. Kanaeva, O. (2013). Corporate Social Responsibility: The evolution of theoretical views. St Petersburg University Journal of Economic Studies, 2, 130-145.

17. Kanaeva, O. (2018). Social imperatives of sustainable development. St Petersburg University Journal of Economic Studies, 1, 26-58.

18. Kell, G. (2013). 12 Years later: Reflections on the growth of the UN Global Compact. Business \& Society, 52(1), 31-52.

19. Kleine, A., \& Hauff, M. (2020). Sustainability-Driven implementation of corporate social responsibility: Application of the integrative sustainability triangle. Journal of Business Ethics, 85, 517-533.

20. Orzes, G., Moretto, A. M., Ebrahimpour, M. et al. (2018). United Nations Global Compact: Literature review and theory-based research agenda. Journal of Cleaner Production, 177, 633-654.

21. Rasche, A., \& Gilbert, D. U. (2012). Institutionalizing global governance: The role of the United Nations Global Compact. Business Ethics - a European Review, 21(1), $100-114$.

22. Rasche, A. (2009). Toward a model to compare and analyze accountability standards - the case of the UN Global Compact. Corporate Social Responsibility and Environmental Management, 16(4), 192-205.

23. Rasche, A., Waddock, S., \& McIntosh, M. (2013). The United Nations Global Compact: Retrospect and prospect. Business \& Society, 52(1), 6-30.

24. Schembera, S. (2018). Implementing corporate social responsibility: Empirical insights on the impact of the UN Global Compact on its business participants. Business \& Society, 57(5), 783-825.

25. Sethi, S. P., \& Schepers, D. H. (2014). United Nations Global Compact: The promiseperformance gap. Journal of Business Ethics, 122(2), 193-208. 